DOI: https://doi.org/10.29038/2227-1376-2020-35-8-23

УДК $159.9(045)$

\title{
СОЦАЛЬНО-КОМУНІКАТИВНА КОМПЕТЕНТНІСТЬ ЯК ЧИННИК ПРОФЕСІЙНОЇ УСПІШНОСТІ ОСОБИСТОСТІ: ГЕНДЕРНИЙ АСПЕКТ
}

\author{
Алсксссва Анна \\ Університет сучасних знань \\ Київ, Україна \\ AnnaOlga@i.ua
}

У статті досліджено особливості впливу соціально-комунікативної компетентності особистості на іiі професійну успішність, а також визначено специфіку зумовленості вираженості зазначених особистісних характеристик у контексті їі психологічної статі. У межах цієї праці професійну успішність розглянуто в контексті єдності іiі зовнішніх і внутрішніх вимірів, а саме кар’єрного зростання, соціального визнання та творчої самореалізації, що супроводжується високим рівнем задоволеності особистості самим процесом діяльності.

Для виконання завдань дослідження застосовано такий комплекс психодіагностичних методик, як анкета «Успіх» (А. В. Алєксєєвої), спрямована на діагностику ціннісно-смислових предиспозицій, що визначають пріоритетну значущість тих або інших вимірів професійної успішності, опитувальник «Соціально-комунікативна компетентність» Г. В. Протасової, опитувальник С. Бем «Психологічна стать» (модифікація А. В. Алєксєєвої), який дає змогу визначити не лише вираженість маскулінно/фемінних складових частин психологічної статі, але й ступінь їі стереотипності, а також рівень психостатевої самооцінки особистості.

За результатами проведеного емпіричного дослідження статусний вимір професійної успішності логічно супроводжується вираженим прагненням до підвищення статусної позиції та, зі свого боку, співвідноситься 3 високим рівнем стереотипності психологічної статі особистості. Сприйняття професійної успішності як прагнення до кар'єрного зростання супроводжується також високою толерантністю особистості до фрустрації, що на рівні психологічної статі зумовлено вираженістю іiі маскулінного компонента. Прагнення до визнання як вимір професійної успішності співвідноситься 3 вираженою орієнтацією на досягнення успіху, передумовою чого виступає психостатева самооцінка, що відображає ступінь відповідності наявних і бажаних проявів маскулінно/фемінних властивостей особистості. Творчий вимір професійної успішності супроводжується вираженою автономністю, чинником якої виступає психологічна маскулінність, а також толерантністю особистості до невизна-

ISSN 2308-3743 (Online), ISSN 2227-1376 (Print)

(C) Алєксєєва А., 2020. Ця стаття відкритого доступу на умовах CC BY-NC 4.0 
ченості, передумовою якої в контексті психологічної статі $\epsilon$ рівень розвитку фемінних властивостей особистості.

Отже, соціально-комунікативна компетентність та особливості психологічної статі значуще впливають на професійну успішність особистості, а саме андрогінна цілісність маскулінно/фемінних властивостей створює найбільш сприятливі умови для професійної творчості.

Ключові слова: кар'єрне зростання, визнання, творчість, психологічна стать, андрогінна цілісність.

\section{Alexeeva Anna. Social Communicative Competence as a Factor Influencing an Individual's Professional Successfulness: in the Context of the Psychological} Sex. The article studies the characteristic influence of an individual's socialcommunicative competence on their professional achievements, as well as the specific sex psychological causality of the examined personal qualities. Within this study, professional successfulness is considered as the integral unity of its external and internal aspects, namely, career growth, social recognition and creative selfrealization, accompanied by high personal satisfaction with professional work.

The following set of psychological examining methods was used to accomplish the research tasks: «Success» questionnaire (A. V. Alekseeva), diagnosing the valuesemantic predispositions that determine high importance of certain aspects of professional success, G. N. Protasova's questionnaire «Social-communicative competence», the Bem Sex-Role Inventory (modified by A. V. Alekseeva), determining not only masculine/feminine components of psychological sex, but also a stereotypification degree in this field and respondents' psychological sex selfattitudes.

According to the performed empirical study, a status as a professional success is logically accompanied by an individual's clear desire to improve their status position and, in turn, correlates with high stereotypification of their psychological sex. An individual's perception of a professional success as career growth is also accompanied by their high tolerance to frustration; the masculine component of psychological sex appears stronger in this case. The desire for recognition as a measure of professional successfulness correlates with a strong focus on success; a psychological sex self-attitude is a prerequisite for such aspirations and reflects the conformity of existing and desired masculine/feminine personal traits. The creative aspect of professional success is accompanied by marked autonomy, which factor is psychological masculinity, as well as by an individual's tolerance to uncertainty, which psychological sex prerequisite is developed feminine personal traits.

Thus, an individual's social-communicative competence and their psychological sex significantly affect their professional successfulness, namely the androgynous integrity of masculine/feminine qualities creates the most favourable conditions for professional creativity.

Key words: career growth, recognition, creativity, psychological sex, androgynous integrity. 
Алексеева Анна. Социально-коммуникативная компетентность как фактор профессиональной успешности личности: гендерный аспект. В статье исследуются особенности влияния социально-коммуникативной компетентности личности на ее профессиональную успешность, а также определяется специфика обусловленности выраженности указанных личностных характеристик в контексте еe психологического пола. В рамках данного исследования профессиональная успешность рассматривается в контексте целостного единства ее внешних и внутренних измерений, а именно карьерного роста, социального признания и творческой самореализации, сопровождающейся высоким уровнем удовлетворенности личности самим процессом деятельности.

Для выполнения задач исследования используется комплекс психодиагностических методик, а именно: анкета «Успех» (А. Алексеевой), направленная на диагностику ценностно-смысловых предиспозиций, определяющих приоритетную значимость тех или иных аспектов профессиональной успешности, опросник «Социально-коммуникативная компетентность» Г. В. Протасовой, опросник С. Бем «Психологический пол» (модификация А. В. Алексеевой), который позволяет определить не только выраженность маскулинно/ феминных составляющих психологического пола, но и степень его стереотипности, а также уровень самооценки личности в контексте ее половой принадлежности.

По результатам проведенного эмпирического исследования статусное измерение профессиональной успешности логично сопровождается выраженным стремлением к повышению статусной позиции и, в свою очередь, соотносится с высоким уровнем стереотипности психологического пола личности. Восприятие профессиональной успешности как стремления к карьерному росту сопровождается также высокой толерантностью личности к фрустрации, что на уровне психологического пола обусловлено выраженностью его маскулинной составляющей. Стремление к признанию как измерение профессиональной успешности соотносится с выраженной ориентацией на достижение успеха, предпосылкой чего выступает самооценка, отражающая степень соответствия имеющихся и желаемых проявлений маскулинно/феминных качеств. Творческое измерение профессиональной успешности сопровождается выраженной автономностью, фактором которой выступает психологическая маскулинность, а также толерантностью личности к неопределенности, предпосылкой чего в контексте психологического пола является уровень развития феминных качеств.

Таким образом, социально-коммуникативная компетентность и особенности психологического пола значительно влияют на профессиональную успешность личности, а именно андрогинная целостность маскулинно/феминных проявлений создает наиболее благоприятные условия для профессионального творчества.

Ключевые слова: карьерный рост, признание, творчество, психологический пол, андрогинная целостность. 
Постановка наукової проблеми та її значення. Питання професійної успішності особистості завжди привертало увагу науковців та практиків, спрямовуючи їх як на визначення основних теоретичних вимірів цього наукового феномену, так і на розробку дієвих стратегій і тактик досягнення успіху в процесі професійної діяльності. Зокрема, на цьому етапі розвитку суспільства стрімке зростання кількості безробітного населення загострює питання пошуку дієвих засобів відновлення потенціалу професійної успішності у випадку вимушеної перерви в професійній діяльності, що передбачає також спроможність до успішної конкуренції з іншими претендентами на робоче місце на сучасному ринку праці.

Отже, зазначена наукова проблематика не залишає сумнівів щодо своєї актуальності та потребує грунтовного дослідження задля пошуку значущих особистісних чинників, що визначають розгортання потенціалу професійної успішності фахівця в просторі сучасного ринку праці. Зокрема, важливе також визначення особливостей актуалізації професійної успішності особистості в контексті ऑї психологічної статі, що дасть змогу створювати більш дієві стратегії розвитку спроможності фахівця до оптимального використання свого професійно-особистісного потенціалу й підвищення рівня власного психологічного благополуччя.

Аналіз останніх досліджень із цісї проблеми. Зазначена проблематика стала предметом численної уваги як вітчизняних, так i закордонних учених, які у своїх дослідженнях намагалися визначити різноманітні аспекти цього наукового феномену.

Так, у розрізі професійної конкурентоспроможності розглянуто професійну успішність через формування кар'єрних орієнтацій фахівця в контексті його здатності до успішної конкуренції з іншими претендентами на ринку праці, особливості застосування методу символдрами як засобу розвитку професійної конкурентоспроможності та через розвиток професійної конкурентоздатності особистості в контексті підвищення рівня ії гендерної компетентності (Смульсон, 2010).

Традиційно професійну успішність у координатах кар'єрного зростання розкрито також закордонними вченими, які визначають як його головні чинники інтелектуальні ресурси особистості, відповідну систему ціннісних орієнтацій (Рора, 2012), а також наявність таких особистісних характеристик, як екстраверсія й проактивність (Turban, 2017). Безумовним є виокремлення в цьому контексті таких чинників 
професійної успішності, як освіта та професійний досвід і наявність певних мотиваційних настанов, які зумовлюють спрямованість особистості на професійні досягнення та стрімке просування кар'єрними сходами (Dwivedula, 2016; Hinson, 2005).

Цікавим аспектом розробки цієї наукової проблематики є визначення гендерних закономірностей кар'єрного розвитку (BuddebergFischera, 2003), а також особливостей впливу статевих гормонів на професійну діяльність особистості. Так, предметом уваги дослідників став вплив тестостерону на професійну успішність жінок, який традиційно позитивно діє на їхню незалежність і цілеспрямованість у процесі досягнення професійних цілей (Russo, 1991).

Але більшість досліджень із цього напряму спрямовано переважно на визначення суто гендерних особливостей професійної сфери особистості, у той час як вплив багатьох вимірів психологічної статі, таких як психостатева самооцінка та рівень стереотипності особистісно прийнятих проявів маскулінності/фемінності, залишається поза увагою дослідників.

Крім того, у процесі аналізу цього наукового феномену розглядаються здебільшого зовнішні виміри професійної успішності, що призводить до недостатньої дослідженості їі внутрішніх аспектів, якот ступінь задоволеності фахівця професійною діяльністю, а також його здатність до творчої самореалізації в процесі професійного самоздійснення, що наголошує на необхідності багатозначного аналізу професійної успішності з різних позицій, що буде окреслено в наступній науковій концепції.

Отже, головна мета цієї статті - визначення особливостей впливу соціально-комунікативної компетентності особистості на іiі професійну успішність, а також специфіки зумовленості вираженості зазначених особистісних характеристик у контексті їі психологічної статі.

Відповідно, до основних завдань цього дослідження віднесено науково-теоретичний аналіз феномену професійної успішності щодо визначення його основних критеріїв і проявів; підбір релевантних діагностичних методик для проведення емпіричного дослідження; визначення особливостей впливу соціально-комунікативної компетентності на професійну успішність особистості; 3'ясування специфіки цього впливу в контексті психологічної статі особистості.

Методика дослідження. Для діагностики ціннісно-смислових предиспозицій, що визначають пріоритетну значущість тих або 
інших вимірів професійної успішності, застосовано анкету «Успіх» (А. В. Алєксєєвої), яка дає змогу визначити актуальність для досліджуваних тих або інших еквівалентів професійної успішності. Так, ця анкета дає змогу визначити домінуючі в професійній діяльності цінності, а саме 3'ясувати пріоритетні смисли професійної самореалізації, які можна віднести до трьох категорій - соціально-професійний статус, визнання й творчість.

Із метою діагностики соціально-комунікативної компетентності особистості застосовано опитувальник «Соціально-комунікативна компетентність» Г. В. Протасової, який складається 3 таких шести шкал, як комунікативна компетентність, толерантність до невизначеності, автономність, індиферентність до статусного зростання, орієнтація на успіх та толерантність до фрустрацій.

Шкала комунікативної компетентності діагностує спроможність досліджуваних до ефективної комунікативної взаємодії 3 іншими, людьми, а саме характеризує людину як привітну, балакучу, щиру, чуйну, гнучку в спілкуванні, таку, котра легко входить у будь-яке товариство, має багато друзів і викликає симпатію оточення.

Шкала толерантності до невизначеності відображає толерантність досліджуваних до невизначених ситуацій, які вони сприймають швидше як виклик, ніж загрозу, а отже, вважають їх простором для творчості та реалізації цікавих завдань, сам процес виконання яких уже приносить задоволення.

Шкала автономності визначає ступінь незалежності досліджуваних від думок навколишніх, їх спроможність висловлювати й відстоювати власну позицію, не звертаючи уваги на статус та авторитет опонента.

Шкала індиферентності до статусного зростання діагностує ступінь задоволеності людини сучасним моментом життя, її природність і зануреність у процес життєздійснення.

Шкала орієнтації на успіх відображає прагнення досліджуваних до отримання значущих результатів своєї діяльності, упевненість у собі, оптимізм та спроможність ефективно долати труднощі й перешкоди на шляху до мети.

Шкала толерантності до фрустрацій свідчить про здатність людини до продуктивної емоційної саморегуляції, що забезпечує можливість ефективного подолання перешкод і проблемних ситуацій.

Для діагностики статевої ідентичності особистості застосовано опитувальник С. Бем «Психологічна стать» (модифікація А. В. Алєк- 
сєєвої), який дає змогу визначити не лише вираженість маскулінно/ фемінних складників психологічної статі, але й, порівнюючи наявні та ідеальні маскулінно/фемінні якості, з'ясувати рівень психостатевої самооцінки особистості. Крім того, модифікований варіант методики уможливлює також діагностику стереотипних образів маскулінності/ фемінності респондентів і визначення ступеня стереотипності їх психологічної статі (Алєксєєва, 2006).

Досліджувана вибірка складалася зі студентів та магістрів Інституту підготовки кадрів Державної служби зайнятості України за фахом «Менеджмент» і «Психологія» та охоплювала 87 осіб.

Статистичну обробку даних проведено із застосуванням програми SPSS (коефіцієнт кореляції за Пірсоном).

Виклад основного матеріалу й обгрунтування отриманих результатів дослідження. У контексті цього дослідження нами визначено основні виміри професійної успішності з урахуванням як зовнішніх, так і внутрішніх аспектів цього наукового феномену, а саме: статусне зростання, визнання професійних досягнень із боку соціуму та творче задоволення особистості самим процесом діяльності.

Так, традиційно, професійну успішність розглядають у вимірах кар'єрного зростання, а отже, підвищення соціально-професійного статусу особистості, що відбувається як через реалізацію схильності до домінування в процесі керування іншими людьми, так і завдяки відтворенню в професійній діяльності певних соціальних очікувань, норм та правил. Результатом реалізації цієї мотивації є отримання високого професійного статусу, тобто певної посади, що еквівалентна відповідному соціальному прошарку та може задовольнити високий рівень професійних амбіцій. Головною мотиваційною тенденцією в цьому сенсі є прагнення до влади, зокрема людина ототожнює себе 3 успішною особистістю й усвідомлює присутність у собі необхідних для кар'єрного зростання особистісних якостей і властивостей.

Іншим виміром професійної успішності $€$ визнання професійних досягнень особистості з боку соціального оточення, тобто підтвердження власної талановитості та надзвичайності з боку соціуму. Визнання професійних досягнень іншими людьми виступає в цьому контексті еквівалентом професійної самооцінки й самоповаги фахівця, який, зі свого боку, докладає зусиль для підтримки визнання власної успішності референтним соціальним оточенням, але відчуття залежності від необхідності успіху часто може навіть певним чином обмежувати можливості прояву його творчого потенціалу. 
Реалізація цього виміру професійної успішності на ціннісносмисловому рівні професійної ідентичності супроводжується вираженою мотивацією фахівця до визнання та слави, що є головним регулятором його професійної активності. Зовнішня успішність у цьому випадку є основою для належної оцінки особистістю власних професійних досягнень і здібностей. Пріоритетність цих аспектів професійної успішності супроводжується прагненням особистості до ефективного професійного самовдосконалення, спрямованого на отримання схвальної оцінки професійних досягнень із боку соціального оточення, що виступає в цьому випадку одним із важливих чинників професійного розвитку. На когнітивному рівні такий вимір професійної успішності часто супроводжується створенням певного професійного іміджу задля отримання позитивних оцінок від референтного соціуму.

Пріоритетність для особистості творчого виміру професійної успішності позбавляє іiі необхідності бути визнаною з боку соціального оточення та значно збільшує рівень ії толерантності до власних помилок і невдач, що сприймаються вже радше як корисний досвід, який можна використати в майбутньому. Позитивний аспект цього виміру професійної успішності - зростання толерантності до невизначеності, котра сприймається не як загроза, а швидше як виклик і поштовх для нових звершень. Навпаки, у потоці творчого натхнення особистість прагне до втілення власних найсміливіших задумів та ідей, що супроводжується зростанням схильності до ризику, що надає свободу творити й перемагати. Отже, коли професійна успішність сприймається як можливість реалізації творчих задумів та ідей, головним для особистості стає вже не необхідність відповідати визначеним нормам і традиціям або бути визнаною з боку соціального оточення, а можливість отримувати задоволення від самого процесу творення, що відбувається в контексті власних уявлень щодо значущості й важливості створюваних продуктів діяльності.

Отже, головним ціннісним виміром творчої професійної самореалізації є можливість реалізації оригінальних творчих задумів та ідей. Емоційний компонент цього виміру професійної успішності утворює відчуття щастя, насолоди від процесу й результатів власної творчості.

Головний мотиваційний аспект творчого виміру професійної успішності - прагнення особистості до втілення та реалізації власних інтуїтивних задумів і поєднання непоєднуваного, що веде до створен- 
ня нових оригінальних продуктів діяльності. Так, саме толерантність до невдач та невизначеності, готовність до ризику й автономність стосовно усталених норм і правил надають людині можливість створювати необхідні умови для реалізації в професійній діяльності власного творчого потенціалу. На когнітивному рівні в межах цієї проекції професійної успішності особистість відчуває себе щасливою людиною, котра відчуває радість і задоволення від самого процесу реалізації власних творчих задумів.

Отже, професійна успішність є поліаспектним феноменом, що охоплює в собі певні виміри, які мають відповідні проекції на рівні ціннісних, емоційно-оцінних, регулятивних та когнітивних компонентів професійної ідентичності. У цьому дослідженні головний акцент зроблено на визначенні особистісних чинників ціннісно-смислових аспектів професійної успішності особистості. Зокрема, як уже зазначено, головною метою дослідження є визначення впливу соціальнокомунікативної компетентності особистості на їі ціннісні пріоритети щодо переважаючої спрямованості професійної діяльності, а також 3'ясування зумовленості зазначених закономірностей у контексті психологічної статі особистості.

За результатами проведеного емпіричного дослідження статусний вимір професійної успішності позитивно корелює 3 показниками, котрі відображають прагнення особистості до статусного зростання $(\mathrm{r}=0,52 ; \mathrm{p} \leq 0,01)$, що є цілком логічним і засвідчує спрямованість досліджуваних на підвищення свого професійного статусу та просування кар'єрними сходами. Зі свого боку, ця шкала тесту, котра діагностує соціально-комунікативну компетентність особистості, позитивно корелює з рівнем стереотипності психологічної статі досліджуваних $(\mathrm{r}=0,33 ; \mathrm{p} \leq 0,05)$, що відображає взаємозв'язок між прагненням людини до відтворення певних стереотипів у професійній діяльності та бажанням відповідати традиційним ідеалам маскулінності/фемінності, типовим для цього суспільства. Наприклад, розповсюдженість у сучасному суспільстві образу маскулінної бізнес-леді, імовірно, породжує прагнення до наслідування гендерних і професійних узірців успішності, що й зумовлює стандартне відтворення певного образу успішної людини, притаманного сучасному українському соціуму.

Іншим важливим чинником статусного виміру професійної успішності в контексті соціально-комунікативної компетентності $є$ толерантність до фрустрації $(\mathrm{r}=0,36 ; \mathrm{p} \leq 0,05)$, що відображає готовність 
особистості протистояти психотравмувальним деструктивним впливам, котрі порушують стан внутрішньоособистісної гармонії, що вимагає від людини розвинутої здатності до продуктивного відновлення внутрішнього емоційного стану задля активізації можливості продуктивного подолання перешкод на шляху до бажаної кар'єрної цілі. Толерантність особистості до фрустрації позитивно корелює з вираженістю маскулінного складника психологічної статі $(\mathrm{r}=0,42 ; \mathrm{p} \leq 0,01)$, що зумовлює стійкість особистості стосовно негативних зовнішніх

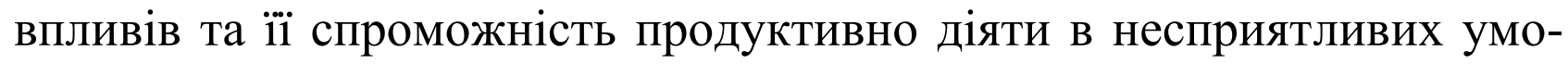
вах і досягати визначених цілей, незважаючи на зовнішні перешкоди та проблеми (рис.1).

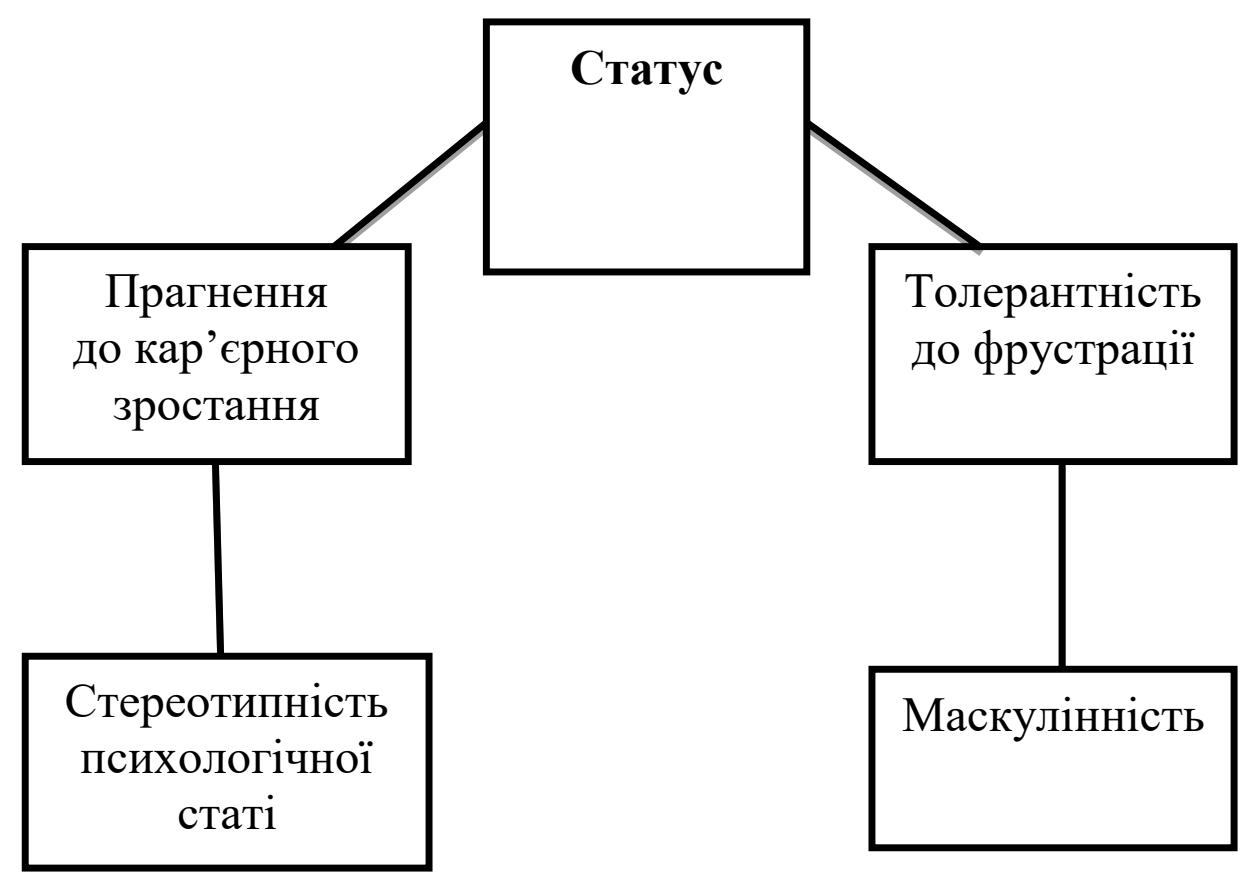

Рис. 1. Кореляційні взаємозв'язки статусного виміру професійної успішності зі складовими частинами соціально-комунікативної компетентності та психологічної статі особистості

Отже, статусний вимір професійної успішності значуще взаємопов'язаний iз проявами соціально-комунікативної компетентності особистості, а також із провідними вимірами ії психологічної статі, а саме з її маскулінною складовою частиною та рівнем стереотипності, що відображає ступінь відповідності маскулінно/фемінних якостей соціально схвалюваним узірцям маскулінності/фемінності.

Наступний вимір професійної успішності, а саме прагнення особистості до визнання своїх професійних досягнень із боку суспільної спільноти, позитивно взаємопов'язаний з орієнтацією особистості на 
досягнення успіху ( $\mathrm{r}=0,35 ; \mathrm{p} \leq 0,05)$, яка отримує суттєву перевагу поряд із прагненням до уникнення невдач. Зазначений кореляційний взаємозв'язок є цілком логічним, адже саме прагнення до отримання високих професійних здобутків часто породжує в особистості бажання публічного визнання результатів своєї діяльності та отримання вагомих підтверджень свого професійного рівня з боку широкої соціальної спільноти. Цей вимір професійної успішності часто поєднується з відчуттям надмірної залежності від власного успіху й породжує необхідність постійного підтвердження значущості професійних звершень із боку референтного соціального оточення, яке виконує функцію певної координації професійної діяльності особистості в напрямі досягнення професійних результатів, що мають шанси отримати відповідне схвалення з боку соціуму (рис. 2).

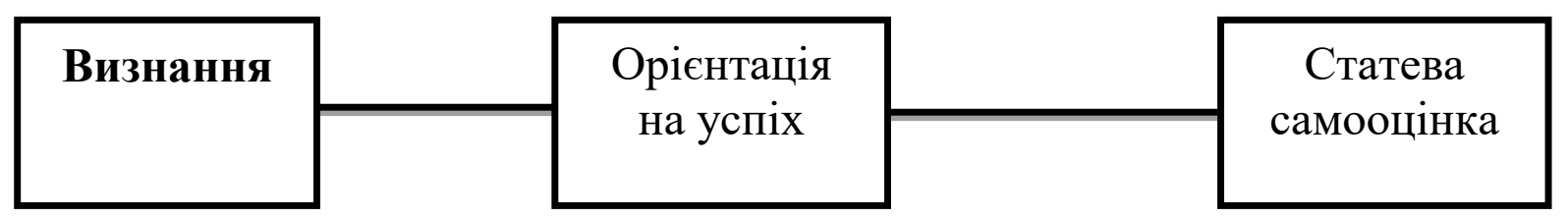

Рис. 2. Кореляційні взаємозв'язки визнання як виміру професійної успішності зі складовими частинами сочіально-комунікативної компетентності та психологічної статі особистості

На рівні психологічної статі орієнтація особистості на досягнення успіху супроводжується високим рівнем психостатевої самооцінки $(\mathrm{r}=0,55 ; \mathrm{p} \leq 0,01)$, а саме відповідністю наявного та бажаного рівня маскулінно/фемінних властивостей, що $є$ свідченням внутрішньоособистісної гармонійності й упевненості особистості у своїх можливостях, зокрема у своїй спроможності отримувати високі професійні результати, які будуть відповідно схвалені з боку значущого соціального оточення. Отже, задоволеність собою в контексті маскулінно/фемінних вимірів психостатевої ідентичності зумовлює продуктивну спрямованість особистості на досягнення успіху в професійній діяльності та отримання вагомих підтверджень власних професійних здобутків із боку соціальної спільноти, що актуалізує їі прагнення до визнання, а саме бажання бути відомою й визнаною з боку референтного оточення, що в цьому випадку є одним із головних критеріїв іiі професійної успішності.

Сприйняття професійної успішності як творчої самореалізації позитивно взаємопов'язано з рівнем особистісної автономності (r=0,44; 
$\mathrm{p} \leq 0,01$ ), а саме здатність особистості бути незалежною від визначених норм, правил і стандартів надає їй можливість для реалізації власних творчих задумів та ідей, що відображають прагнення творця поєднати непоєднуване й створити оригінальні продукти власної діяльності (рис. 3).

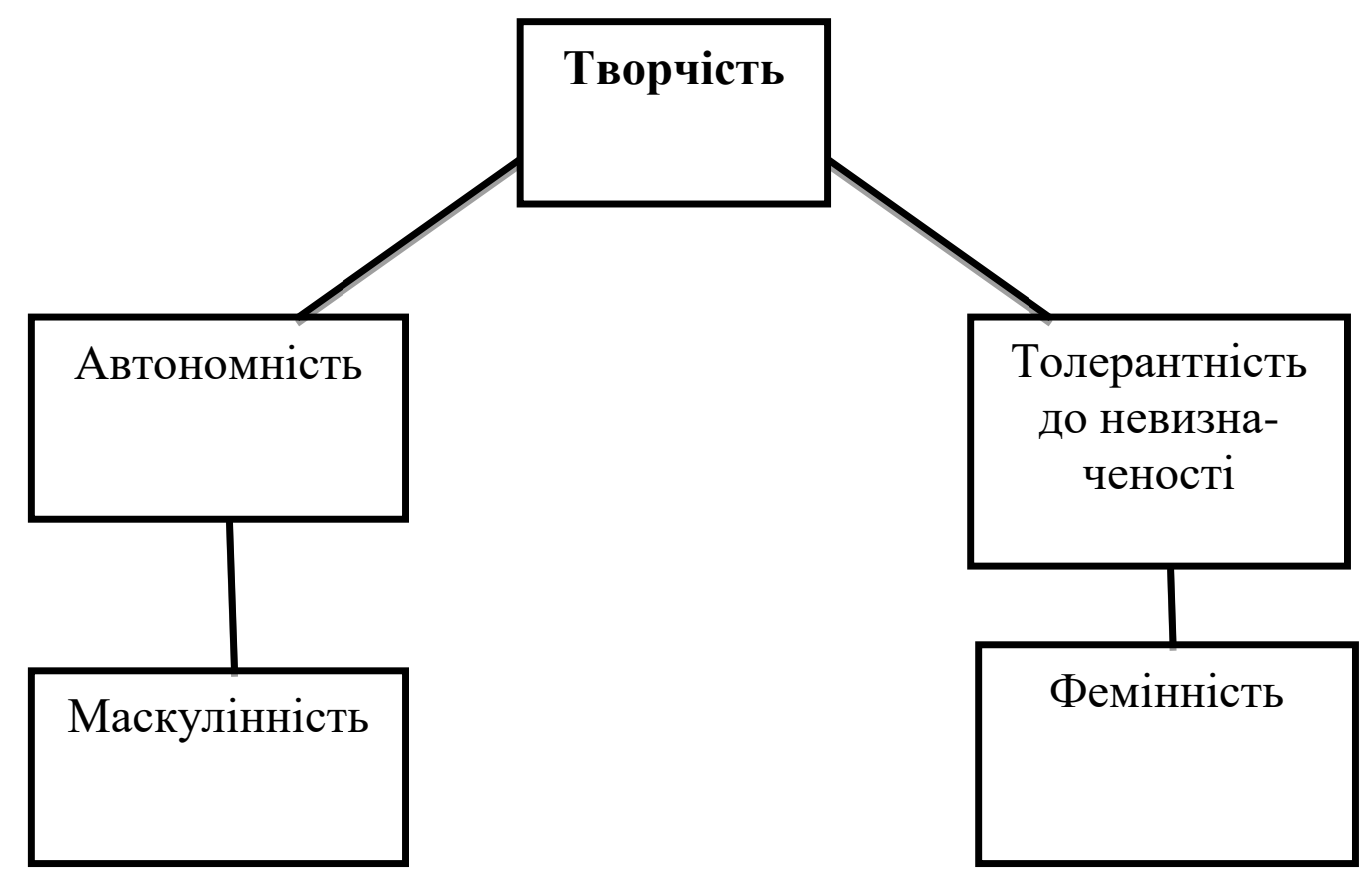

Рис. 3. Кореляційні взаємозв 'язки творчої самореалізачії як виміру професійної успішності зі складовими частинами соціально-комунікативної компетентності та психологічної статі особистості

Цілком логічний позитивний вплив маскулінної складової частини психологічної статі на рівень особистісної автономності $(\mathrm{r}=0,40$; $\mathrm{p} \leq 0,01)$, що в результаті визначає здатність людини до втілення своїх творчих задумів у процесі професійної діяльності.

Іншою цікавою закономірністю цього емпіричного дослідження $\epsilon$ позитивний вплив толерантності до невизначеності $(\mathrm{r}=0,38 ; \mathrm{p} \leq 0,05)$ як складової частини соціально-комунікативної компетентності на спроможність особистості до продуктивної творчої самореалізації, а саме здатність сприймати невизначеність як певний поштовх для активізації творчої діяльності та пошуку нових шляхів виконання завдання $\epsilon$ важливим чинником актуалізації креативного потенціалу й створення оригінальних продуктів діяльності.

На рівні психологічної статі значущою передумовою толерантності до невизначеності $є$ рівень особистісної фемінності (r=0,45; $\mathrm{p} \leq 0,01)$, який зумовлює прийняття особистістю невідомого та неви- 
значеного, що спонукає їі до створення нового й нестандартного всупереч наявним нормам і правилам. Так, існування розвинутої психологічної жіночності надає особистості можливість продуктивно діяти в невизначених ситуаціях, тоді як маскулінна складова частина психологічної статі, навпаки, зумовлює їі схильність до чіткого усвідомлення й аналізу ситуації. I саме вираженість фемінних властивостей $\epsilon$ важливою передумовою реалізації іiі інтуїтивних відчуттів та підсвідомих прагнень.

Отже, гармонійне поєднання маскулінно/фемінних властивостей в андрогінний єдності створює можливість для реалізації творчих прагнень й ідей, а отже, є важливою передумовою актуалізації творчого виміру професійної успішності особистості.

Висновки. Результати проведеного емпіричного дослідження засвідчують наявність значущого впливу соціально-комунікативної компетентності на професійну успішність, а також указують на зумовленість зазначених особистісних характеристик у контексті психологічної статі особистості.

У цьому контексті феномен професійної успішності розглянуто як цілісне поєднання його зовнішніх та внутрішніх вимірів, а саме кар'єрного зростання, визнання й творчої самореалізації в процесі професійної діяльності.

За результатами емпіричного дослідження вимір професійної успішності, пов'язаний із кар'єрним зростанням, співвідноситься 3 вираженим прагненням до підвищення статусної позиції, що, зі свого боку, супроводжується високим рівнем стереотипності психологічної статі, проявом чого є відповідність маскулінно/фемінних рис особистості традиційним для сучасного суспільства ідеалам маскулінності/фемінності. Отже, прагнення особистості відповідати традиційним гендерним узірцям супроводжується також тенденцією до відтворення визначених статусних стандартів у професійному житті.

Вираженість статусного рівня професійної успішності також позитивно взаємопов'язана з толерантністю особистості до фрустрації, що відображає іiі спроможність до продуктивної емоційної саморегуляції задля успішного подолання труднощів і невдач у процесі досягнення професійних цілей та завдань. На рівні психологічної статі значущим чинником толерантності до фрустрації є рівень психологічної маскулінності, яка зумовлює здатність особистості до цілеспрямованої й продуктивної діяльності в складних та несприятли- 
вих ситуаціях, що є важливою передумовою досягнення значущих професійних результатів.

Отже, високий рівень маскулінності й стереотипності психологічної статі зумовлює пріоритетність для особистості кар’єрного виміру професійної успішності, результатом реалізації якого є отримання відповідних статусних винагород у сфері професійного життя.

Прагнення до визнання як вимір професійної успішності позитивно взаємопов'язане з орієнтацією на успіх, що є важливим компонентом соціально-комунікативної компетентності особистості, адже спрямовує $\dddot{1}$ активність на отримання вагомих професійних здобутків усупереч можливим труднощам і перешкодам. На рівні психологічної статі елементом цієї складової частини соціально-комунікативної компетентності виступає психостатева самооцінка, яка відображає ступінь відповідності наявного й бажаного рівнів маскулінно/фемінних властивостей. А саме, чим більшою мірою досліджувані задоволені собою в контексті маскулінно/фемінних вимірів психологічної статі, тим більш виражене їхнє прагнення до успіху та отримання вагомих підтверджень власних професійних здобутків із боку референтного соціального оточення.

Надання переваги творчій самореалізації як виміру професійної успішності супроводжується високим ступенем особистісної автономності й, відповідно, психологічної маскулінності, що надає особистості сміливість для втілення власних творчих задумів та ідей, які можуть суттєво відрізнятися від традиційних норм і правил, що, зі свого боку, призводить до створення оригінальних продуктів професійної діяльності.

Важливим чинником творчого виміру професійної успішності $\epsilon$ також толерантність особистості до невизначеності, що створює належні умови для виникнення й реалізації інтуїтивних відчуттів та ідей у ситуації відсутності чітких правил й алгоритмів діяльності. Цілком логічний позитивний взаємозв'язок психологічної фемінності та здатності особистості продуктивно діяти в ситуації невизначеності, адже саме вираженість фемінних властивостей є головною передумовою реалізації інтуїтивних образів й ідей, які, утілюючись у професійну діяльність, призводять до виникнення оригінальних продуктів професійної творчості.

Отримані результати вказують на те, що саме андрогінний тип психологічної статі $\epsilon$ найбільш сприятливою передумовою продук- 
тивної творчої самореалізації особистості, коли головним стає вже не досягнення визначених професійних цілей, а задоволення й насолода від занурення в саму ситуацію творення, що надає яскравості процесу життєздійснення та надихає на подальші звершення.

Отже, результати проведеного емпіричного дослідження дають підставу стверджувати про наявність значущого впливу складових частин соціально-комунікативної компетентності особистості на їі професійну успішність, які певним чином зумовлені також вимірами іiі психологічної статі.

Отже, професійна успішність, що є цілісним поєднанням кар'єрного зростання, визнання й творчості, зумовлена як соціально-комунікативною компетентністю особистості, так і особливостями ії психологічної статі, а саме андрогінна взаємоузгодженість їі маскулінно/ фемінних складників створює найбільш сприятливі умови для продуктивної творчої самореалізації в процесі професійної діяльності.

Перспективою подальших розробок цієї наукової проблематики $є$ дослідження впливу особливостей психостатевої та психосексуальної сфери на проекції феномену професійної успішності на рівні професійної ідентичності особистості.

\section{Література}

1. Алєксєєва, А. В. (2006). Психологічна стать як чинник становлення особистісної ідентичності у юнацькому віці. Дис. ... канд. психол. наук. ІваноФранківськ, 233 с.

2. Успішність особистості: потенціал та обмеження. Тези доповідей Міжнародної науково-практичної конферениії (2010)/за ред. М. Л. Смульсон, Л. М. Зінченко. Київ, 268 с.

3. Buddeberg-Fischera, B., Klaghofera, R., Abelb, T., Buddeberga, C. (2003). The influence of gender and personality traits on the career planning of Swiss medical students. Swiss Med Wkly, 133: 535-540.

4. Dwivedula, R., Bredillet, C.N., Müller, R. (2016). Personality and work motivation as determinants of project success: the mediating role of organisational and professional commitment, International Journal of Management Development (IJMD), Vol. 1, No. 3, 1(3), 229-245.

5. Hinson, J. M. \& LaPrairie K. N., (2005). Learning to Teach Online: Promoting Success through Professional Development, Community College Journal of Research and Practice, Vol. 29, Issue 6: 483-493.

6. Popa, D., Bazgan, M., Tomozii, S. E. (2012). Personality aspects involved in professional success, Journal of Engineering Studies and Research. Vol. 18, No. 2: $102-109$. 
7. Russo N. F., Kelly R. M., Deacon, M. (1991). Gender and success-related attributions: Beyond individualistic conceptions of achievement. Sex Roles, 25; 5-6: 331-350.

8. Turban, D. B., Moake, T. R., Yu-Hsien Wu, S. (2017). Linking Extroversion and Proactive Personality to Career Success. The Role of Mentoring Received and Knowledge. Journal of Career Development, 44(1): 20-33.

\section{References}

1. Alieksieieva, A. V. (2006). Psykholohichna stat yak chynnyk stanovlennia osobystisnoi identychnosti u yunatskomu vitsi [Psychological sex as a factor in the formation of personal identity in adolescence]. Candidate's thesis. Ivano-Frankivsk (in Ukrainian).

2. Smulson, M. L., Zinchenko L. M. (2010). Uspishnist osobystosti: potentsial ta obmezhennia [Individual success: potential and limitations]. Mizhnarodnoi naukovopraktychnoi konferentsii. - International scientific-practical conference. Kyiv (in Ukrainian).

3. Buddeberg-Fischera, B., Klaghofera, R., Abelb, T., Buddeberga, C. (2003). The influence of gender and personality traits on the career planning of Swiss medical students, Swiss Med Wkly, 133: 535-540 (in English).

4. Dwivedula, R., Bredillet, C. N., Müller, R. (2016). Personality and work motivation as determinants of project success: the mediating role of organisational and professional commitment, International Journal of Management Development (IJMD), 1; 3, 1(3): 229-245 (in English).

5. Hinson, J. M. \& LaPrairie K. N., (2005). Learning to Teach Online: Promoting Success through Professional Development, Community College Journal of Research and Practice, 29; 6: 483-493 (in English).

6. Popa, D., Bazgan, M., Tomozii, S. E. (2012). Personality aspects involved in professional success, Journal of Engineering Studies and Research, 18; 2: 102-109 (in English).

7. Russo, N. F., Kelly, R. M., Deacon, M. (1991). Gender and success-related attributions: Beyond individualistic conceptions of achievement, Sex Roles, 25; 5-6: 331-350 (in English).

8. Turban, D. B., Moake, T. R., Yu-Hsien, Wu. S. (2017). Linking Extroversion and Proactive Personality to Career Success. The Role of Mentoring Received and Knowledge, Journal of Career Development, 44(1): 20-33 (in English).

Received: 01.02.2020

Accepted: 23.02.2020 